\title{
'Splendid isolation': Embracing islandness in a global pandemic
}

\author{
Karl Agius
}

Institute for Tourism, Travel and Culture, University of Malta, Malta

karl.agius.05@um.edu.mt (corresponding author)

Francesco Sindico

Strathclyde Centre for Environmental Law and Governance, University of Strathclyde, Scotland, UK

francesco.sindico@strath.ac.uk

\section{Giulia Sajeva}

Marie Skłodowska-Curie Fellow, Strathclyde Centre for Environmental Law and Governance, University of Strathclyde, Scotland, UK

giulia.sajeva@strath.ac.uk

\section{Godfrey Baldacchino \\ University of Malta, Malta \\ godfrey.baldacchino@um.edu.mt}

\begin{abstract}
Islandness is often considered to be a disadvantage. However, it has helped the residents of islands to delay, deter, and, in some cases, totally insulate themselves from COVID-19. While islanders have been quick to lock themselves down, this has had a tremendous impact on their connectivity and on tourism, which in many cases is their major economic sector. Yet, the association of islands with being safe, "COVID-19 free" zones has helped these spaces to be among the first destinations to restart the tourism economy once travel restrictions were lifted. After several weeks of lockdown, and with the COVID-19 threat still looming, social distancing remained the norm. Travellers were thus eager to immerse themselves in island environments while avoiding crowds and seeking small accommodation facilities in less densely populated rural areas to limit the risks of infection a package offered by several islands in the central Mediterranean. With many travellers opting to travel close to home, islands benefited from domestic tourism - a key market segment for islands in this region. Islands have thus performed relatively well in fighting the COVID-19 pandemic and in restarting their economies; but the pandemic has also exposed challenges including a dangerous overreliance on tourism.
\end{abstract}

Keywords: coronavirus, COVID-19, economic recovery, islandness, islands, Mediterranean, remoteness, tourism

https://doi.org/10.24043/isj.163 • Received February 2021, Early Access April 2021

(C) Island Studies Journal, 2022 
Karl Agius et al.

\section{Introduction}

Small islands allegedly come with structural and inbuilt disadvantages, and are obliged to face multiple challenges because of their small size, insular status, and distance from mainlands (Briguglio, 1995). One key challenge for small islands is their accessibility and a dependency on air and/or sea services to reach and to leave them (Spilanis et al., 2012). An unsavoury combination of expensive, irregular, and limited connectivity has been seen as a structural hindrance for tourism development (Papatheodorou, 2001) - an economic sector which has, over the years, become a major economic activity for many islands (Alberts \& Baldacchino, 2017). And yet, the consideration of insularity and remoteness as a disadvantageous characteristic has been challenged, and islandness has been regarded as something valuable in itself (Baldacchino, 2015; Grydehøj \& Casagrande, 2020).

During the annus horribilis of 2020, these characteristics may have also served to ensure social and physical distancing to a wider extent, secluding and protecting small enisled communities by delaying, deterring, and even completely preventing and insulating these islands and their residents from the spread of the novel coronavirus (COVID-19) pandemic - so much so that geographical isolation, which on several occasions has been ascribed with negative connotations, was considered to be a "blessing" (Ryall, 2020, para. 4). Whereas in December 2019 COVID-19 seemed to be confined to China, within a few months the virus spread extensively and became a global pandemic, reaching 188 countries and territories (Al Jazeera News, 2020). As of September 2020, only a dozen jurisdictions had reported no cases of COVID-19 (Al Jazeera News, 2020). Most of these were Pacific island states, and Putz (2020) confirms that isolated island states were one of three categories of countries with no reported cases of COVID-19.

Preliminary studies suggest that the combination of island geography, remoteness, and jurisdictional powers enabled island and archipelagic jurisdictions to quickly lock themselves down and seal themselves in, thus limiting or pre-empting the number of infections as well as mortality rates (Baldacchino, 2020a). Notwithstanding their limited resources and international clout, many small island states and territories were in a better position to take precautionary measures (such as travel restrictions), and to do so rapidly. The absence of fixed land borders with neighbouring regions that had recorded cases of COVID-19 permitted easier monitoring of tourists arriving or leaving islands, as well as of those travelling between mainlands and islands on a regular basis for work purposes. This is because, in the case of islands, the ferry and cruise ship terminal and the airport are the chokepoints for traffic and serve as sites for any border controls (Baldacchino, 2017). Furthermore, archipelagic islands exhibit "layering" whereby one island may be the mainland of another. In such cases, travelling may involve passing from one island to another, making it easier to implement controls at respective chokepoints (Baldacchino, 2015, 2017).

While relatively isolated, islands are still vulnerable to the threat of global disease (Craig et al., 2020). Numerous islands have recorded COVID-19 infections and deaths. Of the 218 countries and territories on Worldometer's population list, 73 are island/archipelagic states or territories which have recorded at least one case of COVID-19 (Orr, 2020). This implies that geographical isolation alone is not enough to stop the spread of the pandemic and that successful islands have taken additional precautions and measures. Apart from the impact on the health of island populations, infectious disease outbreaks, including that of COVID-19, 
greatly jeopardise the tourism industry due to its reliance on human mobility (Yang et al., 2020). The travel industry has been among the most hard-hit as travel restrictions were introduced around the globe to control the spread of COVID-19 and most tourists cancelled or postponed their holidays, causing a crisis among airlines (Abodunrin et al., 2020; Mhalla, 2020). The impact has been strong on some islands due to their dependence on tourism activities and/or reliance on international air travel; tourism may account for $10 \%$ to $50 \%$ of their total employment (European Commission, 2020a).

Following a period of confinement, authorities began easing restrictions and restarting the non-tourism economy. Later, authorities started to communicate plans to relaunch the tourism economy. With doubts on international travel and when airports and/or borders would reopen (and to which destinations), countries started to push forward "staycations" and domestic tourism as a means to rejuvenate their tourism economy. By the end of June 2020, the European Commission (2020b) recommended the gradual lifting of travel restrictions across Europe and, thus, international travel started slowly to gain pace. Nevertheless, with the onset of a second wave of infections in Europe after August 2020, domestic destinations have remained the most likely choices for tourists in the latter half of the year (European Commission, 2020a). This sets some islands at an advantage, considering that tourism on several Mediterranean islands is dominated by domestic tourism (Canavan, 2013).

Few studies have so far looked at the specific impact of COVID-19 on islands (Baldacchino, 2021; 2020; Galetic, 2020). Against this background, this paper zooms into the Central Mediterranean region, with particular attention to the small islands in the region. The paper explores how such islands have performed health-wise, from the arrival of the COVID19 pandemic to their shores or closest mainland until September 2020, which is considered as the end of the summer season on most islands in the area of study. We will first analyse key actions taken to fight the spread of the pandemic and assess the major challenges encountered. Secondly, we will reflect on the health dimension of the island response, as well as on what the lockdown and its aftermath or precautions taken during the first wave have meant for life on the islands. Thirdly, we will explore ongoing conversations about the recovery process in order to determine the role that sustainable tourism plays in policy debates aimed at relaunching the economy of these small islands.

\section{Methods}

In order to collect relevant data for this paper, a mixed methods approach was adopted. This permitted a collection of information that could not be obtained through one method only, strengthening rigour and validity as well as permitting flexibility in data collection throughout a period when developments were taking place rapidly and constantly (Clark \& Creswell, 2008).

Informal interviews were held with stakeholders to collect data. Expert sampling, which involves the selection of 'typical' and 'representative' individuals, was used to recruit interviewees (Finn et al., 2000). This was possible due to the network that the authors have in the region and their ability to speak Maltese, English, and Italian (the three languages spoken in the research area). Eleven stakeholders were interviewed: locals/second home owners $(n=2)$; tourism industry representatives $(n=3)$; government officials $(n=3)$; and nongovernmental organisations (NGOs) $(n=3)$. The ages of the 11 interviewees varied from 37 to 70 . Two respondents were women and nine were men; this reflects the gender imbalance 
that exists in the respective groups of stakeholders interviewed, especially in the public sector and tourism industry.

Interviews were held throughout September 2020, conducted over the phone and/or online for safety reasons but still permitting valid and high quality interviews (Suryani, 2013). Interviews lasted around 30 minutes each and were kept semi-structured and informal. Necessary ethical considerations were taken into account, providing information to interviewees on the aim of the research and assuring confidentiality.

A checklist of topics was kept on hand as a guide throughout the interviews. Topics discussed included: 1) the health situation on the islands; 2) the role of islandness in the fight against the pandemic; 3) challenges encountered during the COVID-19 pandemic in terms of infrastructure and connectivity; 4) the impact of the lockdown on tourism activity; and 5) measures being taken to relaunch the local economy and the role of sustainable tourism in this regard. The use of a checklist helped to ensure that a consistent range of topics was covered in each interview (Wearing et al., 2002). It is worth noting that the use of interviews in this study has limitations due to the small, unrepresentative sample.

Secondary data was collected through official portals and approved official social media accounts of governments, island authorities, and/or mayors. Other sources included international press, platforms such as the 'Islands and COVID-19' survey developed by Island Innovation and the Strathclyde Centre for Environmental Law and Governance (Sindico et al., 2020; University of Strathclyde, 2020), as well as studies conducted by tourism and business associations among their members (Gozo Business Chamber [GBC], 2020a, 2020b, 2020c; House of Representatives, 2020), which were published between March and September 2020. In addition, the study draws on the multidisciplinary expertise of the authors in the field of islands, governance, and tourism globally as well as in the central Mediterranean region.

The authors sought to secure a saturation of themes when conducting the interviews, which were backed with findings from secondary data. Data collected was analysed manually following the approach adopted by Stoffelen (2019) to analyse data collected from various stakeholders in a cross-border region. Authors faced a number of challenges throughout the research, including limited literature on the topic and the fact that the situation on the ground was developing rapidly (Grydehøj et al., 2020).

Three of the four researchers are islanders, having mainly lived intermittently in the regions of study or on other islands. Additionally, the researchers have conducted research in the same regions prior to this investigation, and therefore have developed considerable "insider" familiarity and knowledge, ties, and contacts with the local communities of their respective islands. The researchers have also engaged in additional research in the field of island studies in other sites. As a result, all phases of the research — including the framing of questions, the process of conducting interviews, and the elaboration of results - were influenced by this background and the "privileged" position of the researchers (Baldacchino, 2008) of having insider information and understanding which, in turn, also allowed them to engage mindfully with local subjects in privileged ways (see, e.g., Savvides et al., 2014). This often led to a co-construction of knowledge and insight; an investigative epistemology that embraces the island studies approach of looking at island related issues "from the inside out" (Baldacchino, 2008, p. 49), similar to what McCall (1997) refers to as the islanders' way of seeing things. This has helped the researchers situate their results and inferences within proper 
context and to propose context-sensitive strategies to protect islands from future challenges that may result from isolation.

\section{Area of study}

The area of study consists of seven islands (two archipelagos and two islands) situated in the central Mediterranean region, straddling the territorial boundary between two sovereign states: Italy and Malta (see Figure 1). Six of these islands belong to the state of Italy: the Pelagian Islands (comprising Lampedusa and Linosa); the Aegadian Islands (comprising Favignana, Levanzo, and Marettimo); and the island of Pantelleria. The seventh island, Gozo, forms part of the state of Malta. Basic characteristics of each of the seven islands are presented in Table 1.

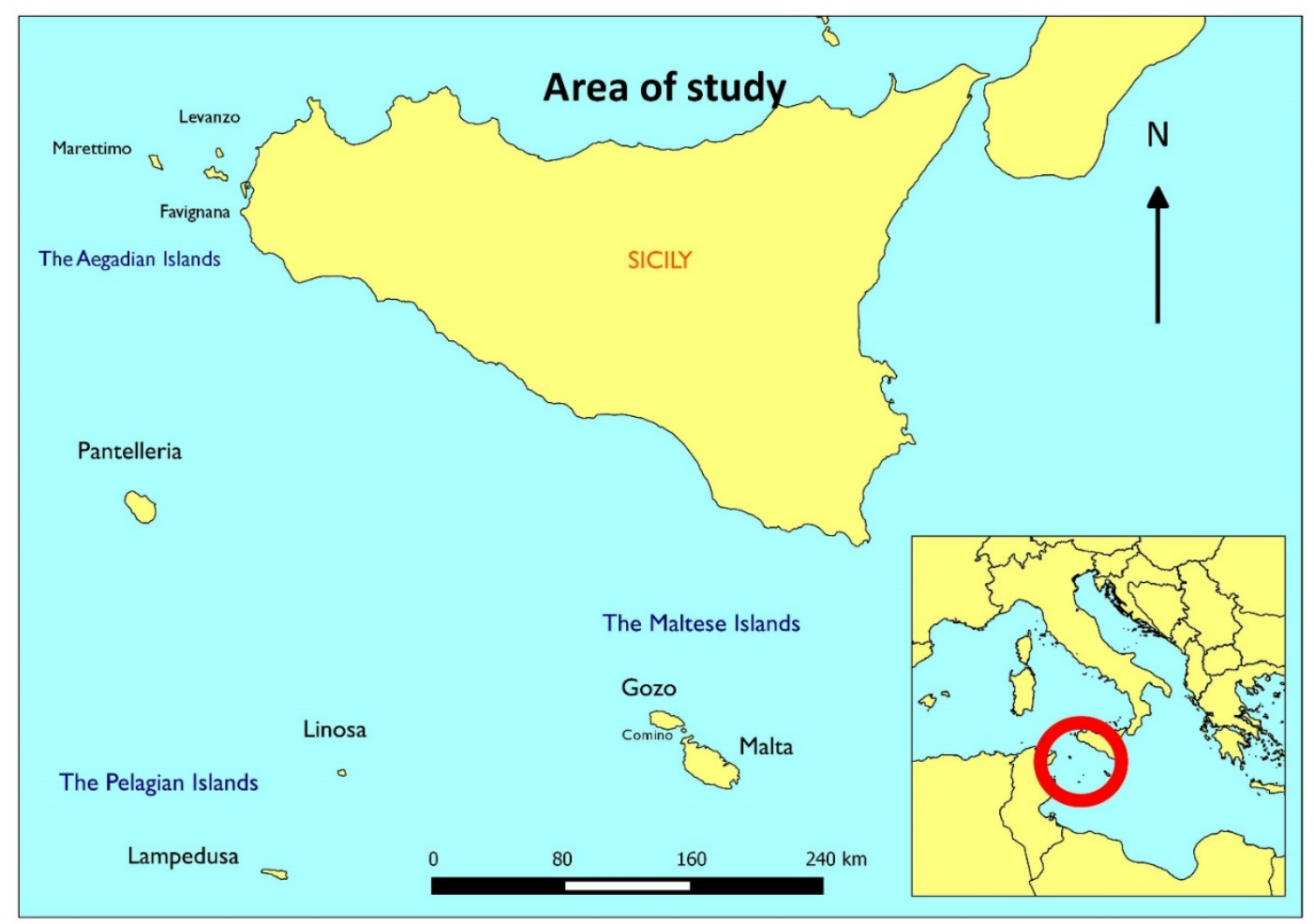

Figure 1. Map showing islands under study. Source: Authors, 2021.

Table 1. Basic characteristics of the islands un theder study (as of September 30, 2020).

\begin{tabular}{|l|l|l|l|l|l|l|l|}
\hline & Gozo & Favignana & Levanzo & Marettimo & Lampedusa & Linosa & Pantelleria \\
\hline $\begin{array}{l}\text { Density } \\
\text { habitants/km }\end{array}$ & 454 & 157 & 39 & 48 & 261 & 81 & 93 \\
\hline $\begin{array}{l}\text { Permanent } \\
\text { population }\end{array}$ & 31,456 & 4,500 & 220 & 820 & 5,703 & 438 & 7,736 \\
\hline Area (km $\mathbf{k m}^{2}$ & 67 & 19.8 & 5.8 & 12.4 & 20.2 & 5.4 & 84 \\
\hline Connectivity & Sea & Sea & Sea & Sea & Air/Sea & Sea & Air/Sea \\
\hline $\begin{array}{l}\text { COVID-19 } \\
\text { cases }\end{array}$ & $\star \star$ & 1 & 0 & 0 & 4 & 0 & 0 \\
\hline
\end{tabular}

$\star$ These figures do not include migrants who tested positive (cut-off date 30/9/2020).

$\star \star$ Official data was not made available by authorities.

Sources: Gallia (2012); Italian National Institute of Statistics (ISTAT; personal communication, 2017); National Statistics Office (NSO; 2019). 
These seven islands were chosen due to their geographical position in the central Mediterranean region. Furthermore, all seven islands are considered to be politically peripheral; they depend on decisions relating to health and the economy taken on their respective "mainlands" (Sicily/Italy for the first six, and Malta in the case of Gozo). The islands are characterised by core-periphery relationships, with most power located on the bigger island of the archipelago (Agius, 2018). In the case of the Sicilian Islands, even higher power is situated further away on a bigger island (Sicily) resulting in what Weaver (1998) described as nested core-periphery relationships.

\section{Results and discussion}

Seven main themes emerged from the analysis of the collected data. These include: (1) the role of islandness and the associated measures taken by islanders to fight the spread of the COVID-19 pandemic; (2) the manner in which the islanders adapted to isolation; (3) the challenges exposed by the pandemic, including health infrastructure and immigration; (4) challenges of connectivity when attempting to "restart" the island economy; (5) the agility of the islands in restarting their tourism economy; (6) new marketing strategies ("COVID-19 free" and social distancing); and (7) the over-dependence of such small island economies on tourism.

Local island communities used their geography and power to protect themselves

Islandness has helped these islands in fighting the ongoing pandemic. However, cases of islands with several COVID-19 infections and deaths have been reported around the world. This implies that COVID-19 cases were kept low across the area of study not just due to geographical isolation but also because of additional measures adopted to reduce risks. While national and regional governments have taken most decisions, islands and archipelagos have used their respective local governments - such as the municipalities in the case of the Sicilian islands and the Ministry for Gozo in the case of Gozo - to implement and adapt these decisions to fit their needs. In addition, islands have added further controls and/or restrictions and have put pressure on regional/national governments where necessary to protect and inform their inhabitants.

While Malta reported its first case of COVID-19 on March 7, 2020, Gozo reported its first case on March 20 (Borg, 2020). Non-essential travel between Malta and Gozo was initially discouraged, and was eventually stopped as of March 31 with few exceptions in place (e.g., travel for medical reasons) (Costa, 2020). As of April 29, there had been no more reported cases from Gozo, with locals claiming the island to be "COVID-19 free". Travel to the island was reinstated on May 3 (Costa, 2020) and new cases started to emerge once restrictions were eased.

Gozo benefitted from restrictive actions to the gateway island (Malta), such as closure of the international airport, as well as from restrictions to inter-island connectivity. Gozo has suffered its share of COVID-19 fatalities; however, its status of "double insularity", combined with measures introduced delayed the arrival of the virus on the island, halted the spread of the pandemic among its population and - unlike the gateway island of Malta - became "COVID-19 free" during the first wave of the pandemic. Even during a second spike of cases that resulted after the ease of restrictions and reopening of the airport in Malta on July 1st, Gozo managed to keep the number of COVID-19 cases under control. In fact, during early 
September 2020, Gozo, with around $6.5 \%$ of the total population of the Maltese Islands, had just $2 \%$ of the total active cases recorded in the country (Micallef Darmenia, 2020). The official total number of COVID-19 cases in Gozo has never been divulged but, following pressure from the Ministry for Gozo, the number of active cases has started to be provided during press briefings directed by the national Superintendent for Health.

On most small Sicilian islands, the only health facilities are emergency medical centres, with one medic per island. As a result, there is no possibility of providing intensive health care to COVID-19 patients, who would have to be airlifted to hospitals in Sicily if serious cases develop. Thus, local communities had no option other than to embrace isolation and take restrictive measures seriously in order to face the crisis. As per a decision taken by the Regional Government on March 8, 2020, those arriving in the region of Sicily from a "red zone" had to self-quarantine for 14 days and inform a doctor of their arrival (Sfragasso, 2020). However, as of March 10, 2020, the Central Government declared all of Italy to be a "red zone", non-essential travel was prohibited, and the lockdown became obligatory in all islands. In addition, as of March 22, 2020, travel between municipalities - and thus from one archipelago to another, or to Sicily - was prohibited, unless for specific urgent matters or health reasons (Comune di Pantelleria, 2020c).

In normal circumstances, islands seek to reinforce connectivity, as their economic gain depends on it. However, in an attempt to reduce the risk of COVID-19 reaching their archipelago, the Mayor of the Pelagian Islands requested a reduction of ferry services in order to better monitor any entry and/or exit from the island. With lockdown in place and travel limited to police force, military service, medics, and those who needed to travel for health reasons, travel between the islands fell substantially. As of March 16, the frequency of hydrofoils linking Sicily and the Aegadian archipelago was reduced and, in the case of Pantelleria and Lampedusa, the ferry service was reduced to one daily crossing from the usual two. In addition, during the so-called "Phase 1" of the pandemic, the Danish Air Transport (DAT) - the company running the Public Service Obligation (PSO) to ensure territorial continuity between the islands and mainland - reduced its flights. The flight linking Lampedusa to Catania was suspended, leaving only one daily flight between Lampedusa and Palermo, which included a stopover at Pantelleria. As mentioned earlier, the introduction of layering in terms of travel has helped to implement controls.

Multiple insularity, limited connectivity, and travel restrictions shielded the Sicilian islands from COVID-19. Sicily, which is the gateway to the Aegadian archipelago, reported a much lower rate of morbidity or mortality as compared to the rest of Italy: in September $2020,0.54 \%$ of the population in Italy had been infected with COVID-19, compared to $0.12 \%$ in Sicily (Gedi Visual, 2020). This served as a buffer for the archipelago: in fact, until September 2020, only one case of COVID-19 had been reported from the Aegadian Islands. This singular case was reported on Favignana, the biggest and most populated island of the archipelago, showing that multiple insularity and layering has also worked in favour of the smaller Aegadian islands, Levanzo and Marettimo.

Notwithstanding their isolation and lower risk of infection, islanders did not let their guard down; nor did they rely solely on their geography. Instead, they abided by the lockdown directives and used masks. The municipality of Lampedusa also closed cemeteries, disinfected streets, and reduced public transport. According to a shop owner from Marettimo, people were taking full precautions by entering shops one at a time. A local from Levanzo 
said that, while there were no cases of COVID-19 on the island, people were afraid and still took the precautions requested by authorities. The island of Linosa is a clear example of how islands took complete advantage of their island condition, and were also unwilling to take any risks, stepping up the national and regional measures to protect themselves. During the initial stages of the pandemic, inhabitants on Linosa prohibited entry into the island to non-locals, without exception. Notwithstanding the national law that allowed medical staff to move across the country for health purposes without the need to quarantine, a medic who was on duty at the emergency medical centre was blocked at the quay due to fear that the virus may be introduced and spread across the small island - a decision backed by the Municipality through an ordinance which applied only for this particular island of the Pelagian archipelago (Scifo, 2020). "Islanders know that they stand a better chance in avoiding invaders - be they human (like armies or pirates) or environmental (like hurricanes or cyclones) or viral (like epidemics) - than in actually resisting them" (Baldacchino, 2007, p. 327).

Pantelleria was also quick in taking decisions and used its authority to further avoid the arrival of the pandemic. On March 4, 2020, the Municipality asked all individuals on the island who had visited COVID-19 hotspots - as identified by national authorities and the World Health Organisation (WHO) - in the previous 14 days to inform health authorities, consult their doctor, and voluntarily self-quarantine (Comune di Pantelleria, 2020a). Through another notice issued on March 10, it became mandatory to avoid any entry or exit from the island, except for work proven to be necessary, for health reasons, or to return to one's residence (Comune di Pantelleria, 2020b). As of March 22, all non-resident workers were banned from entering the territory, with the exception of health workers, police, military, and emergency services. Crew on boats were not allowed to disembark, and loading/unloading had to be done at the port save for a few exceptions such as meat and dangerous products. Yet, even in such cases, delivery persons could not leave their vehicles at any time (Comune di Pantelleria, 2020c).

Overall, results show that islands were quick to close their borders and limit their connectivity to residents and delivery of cargo. Drastic decisions taken by the islands, together with cautious behaviour from local communities, paid off as they managed to keep the COVID-19 pandemic completely away or under control. The closing of air and sea ports has not been an easy decision for any of the islands, however. Tourism, a major economic sector for all these islands, depends on these connectivity services, and the drop in tourism led to an economic "domino effect" with impacts on various other sectors such as fisheries, catering, and hospitality.

\section{Islands are well-prepared for isolation}

Isolation is a challenge that islanders face constantly. Small islands that can be accessed only by sea depend on sea transport to connect with other islands or mainlands, and storms, including those taking place in summer, can isolate islands for a substantial period of time. The COVID-19 pandemic has taken the isolation of islands to another level; even so, islands were generally well prepared for this eventuality.

One example that manifests how islands are accustomed to adapting to prolonged isolation is related to education. The COVID-19 pandemic kept thousands of students at home and pushed educational institutions globally to shift their activities to virtual platforms and move most lessons and lectures online. In Favignana, however, COVID-19 did not catch 
the school completely unprepared. In fact, insularity has long triggered this process on islands (Dominioni, 2020); the National Plan for Digital Schools kicked off in the scholastic year 2005/06, launching first in the Aegadian Islands and later in the Pelagian Islands (Mangione et al., 2015). Through a project called "Marinando", students across the Aegadian Islands have been able to follow their studies from the small schools located on the islands (Lucchini, 2010). A local from Marettimo said that whilst schools were closed and teachers did not visit the island due to restrictions, students could still continue with their studies from home as they were used to e-learning and distance learning.

Local communities are also used to living in isolation. As a local from Marettimo said, "Living on the island is as if you are in quarantine all year round, apart from the summer season." Speaking on the sense of feeling alone and isolated, a local said that nothing had changed on the island because the population always dropped in numbers throughout winter. A policymaker from Marettimo added:

Several journalists asked us about the impact of the lockdown and reduced connectivity services on the local community. What they did not consider is that we are used to living in complete isolation for long periods of time. It is not the first time that we got completely isolated due to the suspension of ferry boats and hydrofoils as a result of bad weather. In fact, the islands faced no problems with food provisions as everyone is well stocked for any eventuality.

The provision of food and other essential goods was not negatively impacted thanks to a combination of local preparedness, the wide use of local products (mostly from fishing and limited agriculture on some islands), and the frequent delivery of goods from larger islands.

\section{COVID-19 exposed island limitations: Health and immigration}

COVID-19 has exposed a number of challenges faced on a daily basis by those communities who reside on islands year-round. In the case of Pantelleria, the pandemic exposed the health challenges faced by the local community. The maternity ward on Pantelleria was closed on March 2, 2020. Although this closure was due to a downsizing exercise by health authorities and unrelated to the COVID-19 emergency, local families expecting newborns expressed anger at the added discomfort of traveling to Sicily, which was not COVID-19-free like Pantelleria, particularly at a period when connectivity was reduced (Allaby, 2020). Local authorities voiced concerns over the possibility of the virus being introduced to the island; a petition was circulated and the mayor, vice mayor, and the president of the city council went on a hunger strike for over three days to send a message (Allaby, 2020) leading the regional government to promise compensation to affected families. Those living on the Pelagian Islands are used to this scenario. A restaurant owner from Lampedusa recalled how he had to close the restaurant and travel with his wife, children, and mother-in-law when his wife was about to give birth, losing income from his work and paying additional travel and accommodation costs in Sicily. The need for basic health infrastructure has become more evident in these times; in fact, the Mayor of the Pelagian Islands has initiated a feasibility study to build a hospital on Lampedusa (BlogSicilia, 2020).

According to a policymaker from Marettimo, COVID-19 was "a missed opportunity in terms of health infrastructure and investment." Whereas several mainland regions upgraded 
their health centres, little attention was given to the emergency medical centres in the archipelago, which have limited equipment and infrastructure. Furthermore, the number of staff did not change throughout the pandemic. The lack of investment in health has also been outlined by the island municipalities in the manifesto presented to authorities (Associazione Nazionale Comuni Isole Minori [ANCIM], 2020) expressing concern over their capacity to monitor health risks when people start to travel.

In the case of the Maltese archipelago, the first death due to COVID-19 was reported from the island of Gozo in early April 2020 (Vella, 2020). This sparked a lot of fear as there are no infectious disease specialists in Gozo and just one respiratory physician (The Shift, 2020) and the island thus relies on the main, general hospital in Malta. In this regard, the air ambulance was upgraded to two helicopters (House of Representatives, 2020), and a testing hub was also opened by the end of March 2020 to increase COVID-19 testing on the island. The fact that Gozo has its own representatives forming part of the central government meant that, unlike the Sicilian islands, it could lobby Cabinet directly on the needs of the Gozitan community, including in terms of health services.

In the case of Lampedusa, COVID-19 shed more light on the immigration problem. The housing and detention of undocumented migrants on the island has long been a challenge for Lampedusa, and has negatively affected the island's reputation as a tourism destination (Agius, in press). Indeed, a surge in the arrival of migrants raised tensions during the COVID19 pandemic out of fear that they might introduce the virus into a small island community that is both isolated and with limited health services. Locals also feared that, since some of the migrants arriving on the island had tested positive for COVID-19, this would ruin the "COVID-19 free" image the island had established for itself, impacting the potential summer tourism season, which is a breaking point for most families on the island.

As of March 2020, several immigrants began arriving on Lampedusa. The mayor assured locals that necessary measures were being taken, including that immigrants were being tested for COVID-19 and that no one was being allowed to leave the detention centre. The situation became out of control in April when a centre that was originally built to house under 100 persons became overcrowded, holding ten times that number and making it impossible to ensure social distancing (BBC News, 2020). Hundreds of migrants were relocated to Sicily, after being first transferred on a cruise ship serving as an offshore quarantine station (Baldacchino, 2021). The "immigration problem" was thus shifted to a bigger island (Sicily). This was a political victory for the islanders of Lampedusa who had lobbied extensively in favour of quarantining migrants on offshore vessels.

Islands remain dependent on higher levels of power, such as regional and national governments found on larger islands or mainlands, for key decisions such as those related to health and immigration. In some cases, they have managed to successfully lobby these higher powers, as seen in the case of the migration crisis. On the other hand, in the case of health services, islanders have yet to counter rational arguments based on economies of scale that deprive them of key services.

\section{Connectivity key to relaunch tourism}

Connectivity is a key critical aspect of island life that was severely affected during the COVID19 pandemic. Suspension of connectivity and travel limitations taken at national and regional levels had a drastic impact on the economy of the seven islands included in this study. Fishers 
from Favignana said that, due to the disruption of tourism, they were unable to sell fish which were usually sold to restaurants. While both the island of Lampedusa and the island of Pantelleria faced various limitations with air and sea travel prior to the COVID-19 pandemic due to low frequency and seasonality of flights, hefty prices, no real low-cost airlines, and unreliable ferry services (Agius et al., 2021), connectivity services during the pandemic and their return to full operation have proven to be more challenging.

The small planes and the reduced service available during Phase 1 of the pandemic meant that, at times, there was hardly any social distancing on the planes. On one particular occasion, passengers refused to board, forcing the company to run two flights (TP24, 2020). With measures implemented, planes could eventually take only 30 passengers; 15 from each island (La Sicilia, 2020). The situation became even more complicated as of May 4, 2020, when lockdown was eased and travel within the region was allowed, albeit under strict conditions.

The reduced seats on board flights due to the COVID-19 measures had an impact on local communities. Those travelling for work or who had to visit the mainland for health reasons were stuck on the island or were unable to return home immediately. This is particularly challenging given that inhabitants always need to travel to mainland Sicily for specialist consultancy or clinical treatment. To make matters worse, some plane seats were reserved for members of the police force or the military serving on both islands (Mobilita, 2020), further reducing the number of available seats.

At the start of the COVID-19 pandemic, municipalities were in favour of reducing connectivity to facilitate controls. But, with no end in sight for the pandemic, the summer season approaching, and pressure from operators mounting, the situation was seen in a different light. Appeals were made to DAT by the mayors of Pantelleria and the Pelagian Islands to increase the number of flights as per pre-COVID-19 times, including three daily flights to Lampedusa and direct flights to Pantelleria without any stopover, or to use planes with higher passenger capacity (Amato, 2020). Travel was restored to its "normal" status by June 2020; however, due to COVID-19 measures and reduced capacity on board chartered flights, ticket prices increased dramatically. Operators feared that fewer tourists would visit the islands and that chartered flights would fail to break even (LiveSicilia, 2020). Flights operated by Alitalia, the national airline, linking Rome and Milan to Trapani (the closest airport to the Aegadian archipelago) were cancelled. Domestic tourism (mostly from the North of Italy) is the main source of tourism to the Sicilian islands, and such drawbacks were serious blows to the badly needed push for the tourism industry.

Shortly after the lockdown was lifted in the beginning of June, the frequency of ferry and hydrofoil services was also restored to almost pre-pandemic levels, although with less capacity. The capacity of hydrofoils was reduced from 300 to 224 passengers to ensure social distancing on board. Following a request by tourism operators due to the presumed prolongation of the summer season, and in order to make up for the missed tourism months, the hydrofoil service between Sicily and Pantelleria and between the Pelagian Islands was extended to the month of October (Il Giornale di Pantelleria, 2020). Policymakers also proposed prolonging seasonal air services, such as the flight between Pantelleria and Catania.

In the case of Gozo, connectivity was never reduced, but travel restrictions were in place. Nevertheless, the importance of adequate connectivity for Gozo's economy became more evident during the COVID-19 pandemic. As a result, in their proposals for economic recovery, business representatives and policymakers from Gozo pushed forward the discussion 
of a permanent link between Gozo and Malta, the reestablishment of air links, and the introduction of a fast ferry (GBC, 2020b; House of Representatives, 2020).

While the COVID-19 pandemic has exacerbated challenges faced by islands, as underlined by municipalities of the Sicilian Islands, it failed to draw any serious attention to the endemic problems that islands have faced over the years due to their geographical condition and their weak institutional and socio-economic power (ANCIM, 2020). However, the Pelagian Islands managed to use the pandemic and its negative impact on major economic sectors (i.e., tourism and fisheries) to push for a "state of emergency" as declared by the Regional Government. This is considered as an important step towards eventually seeking direct help from the national government, including tax advantages (ANSA, 2020).

\section{Islands faster than other destinations to restart tourism}

Lockdown was eased on May 4, 2020, allowing travel across municipalities for those who own a second home in the same region. As of May 18, travel bans within the same region, and thus between islands and the territories falling under the Region of Sicily, were lifted. Furthermore, as of June 3, the central government in Rome allowed inter-regional travel and reopened airports for inbound flights from Europe (Pelosi, 2020). With travel restrictions lifted and connectivity slowly reinstated to its former status, economic activity — including tourism - could resume. Tourism in Sicilian islands usually starts in May/June (depending on the island); in the annus horribilis of 2020, it gradually picked up by July.

A local from Lampedusa said that once chartered flights started to operate normally as of mid-June, tourism improved to the extent that the island was "full of tourists between July and September." Beaches were full, too; signs had to be placed at the access point of Rabbit Beach - once voted as the best beach in the world — to remind beachgoers to respect social distancing. An operator from Lampedusa said, "taking into consideration what was taking place on a global level, one cannot complain. It is true we lost a month of tourism; but otherwise we had a good summer." Likewise, an operator from Linosa said that whereas until June the season was closed, between July and September several tourists from north Italy and Sicily had visited the island. There has also been significant regional tourism, with several visitors coming from Sicily. An operator from Lampedusa said that some of his clients had been booked to travel to other tropical islands outside of the European Union but, given the travel restrictions, they instead opted to visit the most remote island in Italy.

Tourism also resumed in the Aegadian Islands, even if with a two-month delay and much lower numbers at first. Although Favignana is one destination in which tourists travelling to Sicily showed most interest (Ruta, 2020), initial numbers in June and July were still far below the usual massive records; in the summer of 2019, the islands' population increased from 4,500 to more than 66,000 people (Libero Consorzio Comunale di Trapani, 2019). However, according to operators, numbers increased in August and September. A policymaker from Marettimo said that while July was slow, a record number of tourists visited the island in 2020; "It is almost incredible. Considering developments, we were not expecting these numbers." Visitors were mainly domestic tourists from the north of Italy and regional tourists from the island of Sicily, the largest and most populated island in the Mediterranean with a resident population of over five million.

Pantelleria is popular among domestic tourists both from mainland Italy and from Sicily. For this reason, before the summer season, COVID-19 was considered as a mixed blessing, 
especially since tourists were reconsidering international travel and would want to travel closer to home (Mariano, 2020). As predicted, an operator from Pantelleria said that tourism in May and June was lost but, as of July, the islands experienced a surge which was bigger than in usual years. One policymaker said, "One expected less tourists; but instead more people travelled to the island."

Before the COVID-19 pandemic, the island of Gozo was already visited by Maltese residents throughout various periods of the year, especially in summer. Domestic tourism contributes significantly to the Gozitan economy: domestic tourists account for $54 \%$ of the total tourism demand in Gozo (NSO, 2020). The lack of confidence in overseas travel, combined with Gozo's presumed "COVID-19 free" status following the first wave, presented an opportunity for the island to attract more domestic tourists.

Remarks made by stakeholders confirm that islands in the central Mediterranean region benefited from the fact that domestic and 'visiting friends and relatives' (VFR) tourism was the first to reboot, having been encouraged by authorities once restrictive measures were relaxed. This was an added value since several small islands have a predominantly domestic tourism market and since their communities travel overseas to study and work and return from time to time, especially in the summer period.

With respect to domestic tourism, one should keep in mind that whereas in other circumstances bigger islands that serve as the outer core or the inner core have negative relationships with the periphery on various grounds, such as power struggle, COVID-19 has established a new form of positive relationship. COVID-19 has triggered - or, in some cases, reinforced - a trend of travelling and exploring destinations closer to home. In this regard, the periphery has become an ideal destination for those living in the inner or outer core due to the distance and the relative safety of the periphery.

Decisions taken at the beginning of the COVID-19 pandemic paralysed the tourism sector; however, overall, the drastic measures taken and implemented by these seven islands have proved largely successful once lockdown measures and restrictions were relaxed for postlockdown. Indeed, once restrictive measures were lifted, islands were in a better position to restart tourism activity. Postponement was not an option; most islands have a short tourism season, during which they make their living for the entire year. Thus, out of sheer necessity, they had to quickly start the tourism season ahead of fears of a second wave.

Domestic tourism has helped islands to recover economically, but this has come with consequences. Operators and policymakers from Pantelleria expressed concern that while the island typically attracts niche and high-end tourists, in 2020 the island instead attracted mass tourism activity. This might have been due to the fact that other islands known for partying had several cases of COVID-19 whereas Pantelleria was COVID-19 free, in addition to tourists' preference to travel closer to home. This led to discontent among the local community and has raised a debate on what type of tourism the island wants to attract. Similar concerns were reported from the Aegadian Islands. The archipelago usually hosts domestic visitors, but also many European tourists as the Trapani airport was previously well-connected to various European destinations. Fear of travelling overseas and preferences to travel closer to home meant that fewer international tourists visited the archipelago in 2020. This was felt by operators in terms of both numbers and quality of tourists. An operator from Levanzo said that, owing to flight restrictions from some high-risk destinations, fewer foreign tourists visited the island, which "was a blow for those working in cultural and ecotourism as most 
domestic tourism revolved around the seaside." This has once again triggered discussions on the need to study, reflect upon, and tackle tourism seasonality and to focus on niches that can support this shift, including ecotourism.

New marketing strategies: "COVID-19 free" and social distancing

The fact that islands managed to restart tourism quickly has been attributed to a number of factors, including marketing strategies used. Several islands have boasted zero infections, branding themselves as "COVID-19 free". This has become a new quality label for islands across the area of study and is now used by islands as a marketing tool to encourage tourists to visit while ensuring safety and peace of mind.

By the end of April 2020, shortly after the first wave started, Gozo managed to eliminate all active cases of COVID-19. Operators and tourism stakeholders were quick to label the island as "COVID-19 free" in an attempt to encourage more people from Malta to spend their summer on the sister islands.

According to operators and policymakers from various islands, the "COVID-19 free" label has left its impact on tourism activity. The surge in tourism on islands such as Pantelleria was connected to their being considered a safe destination. The management body of the National Park on Pantelleria promoted a visit to the park using the "COVID-19 free" label in its marketing strategy (Cozzo, 2020).

Official cases of COVID-19 on some islands were zero or negligible; but the islands have also played down the cases. Perhaps they were not willing to compromise their "COVID-19 free" image that was so crucial to their tourism-driven economy. An operator from Favignana quickly dismissed the one case of infection reported on the island in September, saying that the case was reported from the prison and that the person concerned was in isolation. Similarly, the case of a resident on Lampedusa who had travelled to Italy's red zone and the three medics found to be infected were dismissed by those interviewed, claiming that these cases were isolated and that there was no need for one to be alarmed.

Islanders have deployed their imagination, playing to their strengths in order to resuscitate their tourism season. Apart from the "COVID-19 free" label, islands have also capitalised on the opportunities that their characteristics provide in terms of social distancing and low absolute numbers of tourists - features that other destinations such as big cities and urban centres cannot easily provide. Some $80 \%$ of accommodation on Pantelleria consists of traditional dwellings known as dammusi, which are secluded in rural areas and are thus ideal for ensuring social distancing between different clusters of people (Cozzo, 2020). In addition, the island has a small population and annual tourist arrivals of less than 100,000 (TP24, 2019), making it uncrowded even during summer months. Indeed, Pantelleria has been tagged as the ideal destination for Summer 2020 as social distancing is the norm on the island (Pes, 2020; Rossi, 2020). How times have changed; isolation has become a virtue, and what before was considered as a limitation has become valuable (Rossi, 2020).

Gozo too has a strong rental sector, with families usually opting to book traditional farmhouses, rather than hotels, throughout their stay (Muscat, 2014). This helps to keep clusters of people together within their own social "bubble", avoiding crowding and thus offering more peace of mind to visitors. Several Maltese residents spent their summer holiday in Gozo during 2020 and rented farmhouses with full amenities (including a pool) to stay indoors and avoid the crowds on the few beaches on the island. 
Furthermore, after entire weeks spent indoors due to official lockdowns, voluntary and obligatory quarantines, and limited time outdoors for preventive reasons, many were keen to spend time away from their habitual urban spaces and reconnect with natural and rural environments. In spite of their small size and intense human impact, islands in the current study still offer extensive areas where nature has been preserved. Small islands in particular have been found to have greater potential for sustainable tourism (Agius et al., 2019), and this has also changed the perception of local communities about protected areas. From a space associated with building and planning restrictions, protected areas have become a space offering a new opportunity to relaunch a niche tourism industry based on small tourist numbers but greater revenue per capita. The institution of the National Park of Pantelleria, which covers $80 \%$ of the island (Ente Parco Nazionale Isola di Pantelleria, 2020) and was established in 2016, has been controversial but was eventually considered as an opportunity to relaunch the tourism sector. Park managers interviewed for this paper said that several people visited the island because of the park.

\section{Islands' dependence on the mainland and tourism}

It is clear that the seven islands under study coped fairly well with the "corona crisis". However, the COVID-19 pandemic did expose their economic vulnerability and dependence on the mainland, especially for what may be considered as the catalyst for economic success: tourists. The islands' tourism-dependent economies were in shock during the first wave of COVID-19. In May 2020, the mayors of the Sicilian islands asked the Regional Government to provide financial support to the tourism sector (Comune di Pantelleria, 2020d), and the National Association of Small Island Municipalities (ANCIM; 2020) issued a manifesto calling for financial support to counteract unemployment and poverty pertaining to the seasonality of the tourism sector.

Once global trends of infections started to decline in early summer 2020, discourse shifted from one of health crisis to one of economic recovery and relaunching tourism. Some locals not working in the tourism sector feared that the relaxation of measures which had worked well to protect islands from COVID-19 may lead to the introduction of the virus. This fear escalated in light of the limited health resources and acute vulnerability of these islands, due to their elderly populations and the fact that most domestic tourists would originate from areas considered to be "red zones". However, the sentiment was different among those that earn a living from tourism. Locals working in the tourism sector were ready to compromise or find a balance between their health and their livelihood; tourism is practically the only significant economic activity in the private sector of these islands, and one upon which several other sectors depend.

An operator from Levanzo said that while islanders were worried about the possibility of tourists introducing the virus on the island - which was, until June, COVID-19 free they were also delighted and not afraid to start working. This is largely because the tourism season on the island is short and thus one had to make the most of what was available, taking all health precautions such as using face coverings and following hygiene protocols.

Throughout early March 2020, locals from the Aegadian Islands were encouraging the mayor to expel second home owners who came from the "red zone" on the basis of fear. By June, however, interviewed operators were quick to augur that once travel bans were lifted, 
tourists would visit their islands irrespective of their origin, whether that be Sicily, Italy's "red zones", or other countries.

Similarly, Gozo residents also had a change of heart. Initially, residents were uneasy with the arrival of Maltese crossing to the island. Tensions increased when some Maltese residents who owned summer residences in Gozo moved to the sister-island during the first months of the pandemic, even though they opted to self-quarantine on arrival. While pressure led to a limiting of travel between the sister islands, the ensuing economic crunch prompted lobbying from stakeholders and, later, the introduction of measures that favoured more travel (GBC, 2020a). Ferry service tariffs were reduced drastically throughout the month of July to encourage more Maltese and foreigners to visit Gozo (TVM, 2020).

The decision to open the doors to tourists to visit the islands did not backfire, considering that some islands had zero COVID-19 cases and others had negligible or few cases, even after the summer season. However, the dependence on tourism needs to be addressed: post-COVID-19 discussions need to focus on how these islands can plan a more resilient future rather than proceed with a "business as usual" approach. The opportunities presented by digital innovation and the fulfilment of sustainable development goals are to be taken seriously into account (Sindico et al., 2020).

\section{Conclusion}

During the first months of the COVID-19 pandemic, the virtues of isolation were selfevident: trumping their usual association with vulnerability, numerous small islands have used their isolation, remoteness, and agency resources to protect themselves from the spread, or even the onset, of the pandemic. In the case of archipelagos, peripheral islands with double or multiple layers of insularity have seen fewer cases of the virus, achieving an enviable "COVID-19 free" status. Self-isolation and physical distancing come naturally to many islanders who have learnt how to live with limited connectivity and the consequences of bad weather, trade disputes, or interruptions in a fragile logistics supply chain that may end up interrupting even their supply of essential goods and services.

As destinations attempted to rebuild trust among tourists seeking safe environments for their holidays, several islands branded themselves as "COVID-19 free" destinations. This presents a new scenario of certification and a 'quality label' that should encourage travellers to visit such destinations for the months to come. The reliance of several islands on domestic tourism and their limited international market had previously been seen in a negative light; however, in the context of COVID-19-related developments, this situation turned out to be a positive aspect and secured visitors. Restrictions were lifted and travel restarted in June/July 2020, and islanders had to adapt to a shorter tourism season, working long hours to earn enough money to keep them going throughout the year. These islanders have amply demonstrated agility, flexibility, and creativity: they were among the first to relaunch their tourism economies to pre-COVID-19 levels, they marketed isolated accommodation facilities and low-density parks, and they promoted rural and ecotourism as well as diving - all practised in small groups and ensuring social distancing. Islands have also demonstrated themselves to be one step ahead compared to mainland regions both in terms of stronger lock-down measures as well as in terms of quicker recovery. COVID-19 has also exposed structural challenges, including limited and basic health facilities, migration challenges, 
reliance on authorities based elsewhere, and island economies' dependence on a tourism sector which was highly impacted due to travel restrictions and reduced connectivity at the start of the pandemic.

A summer of unprecedented high numbers of tourists allowed these seven Mediterranean islands to make up for past (and probable future) months of travel restrictions as the pandemic rages on. Now, all talk is about vaccines and how the pandemic may be finally brought to heel. Meanwhile, small islands continue to highlight both the virtues of isolation, as well as the dangers of overdependence on tourism.

\section{Funding}

This project has received funding from the European Union's Horizon 2020 Research and Innovation programme under the Marie Skłodowska-Curie Grant Agreement No. 841546.

\section{References}

Abodunrin, O., Oloye, G., \& Adesola, B. (2020). Coronavirus pandemic and its implication on global economy. International Journal of Arts, Languages and Business Studies, 4, 13-23.

Agius, K. (in press). Doorway to Europe: Migration and its impact on island tourism. Journal of Marine and Island Cultures.

Agius, K. (2018). Assessing the ecotourism potential of central Mediterranean islands with a case study on marine ecotourism [Unpublished Ph.D. dissertation]. Institute for Tourism, Travel and Culture; University of Malta.

Agius, K., Theuma, N., \& Deidun, A. (2021). So close yet so far: Island connectivity and ecotourism development in central Mediterranean islands. Case Studies on Transport Policy, 9(1), 149-160. https://doi.org/10.1016/j.cstp.2020.11.006

Agius, K., Theuma, N., Deidun, A., \& Camilleri, L. (2019). Small islands as ecotourism destinations: A central Mediterranean perspective. Island Studies Journal, 14(2), 115-136. https://doi.org/10.24043/isj. 97

Al Jazeera News. (2020). Which countries have not reported any coronavirus cases? Al Jazeera News. https://www.aljazeera.com/news/2020/04/countries-reported-coronaviruscases-200412093314762.html

Alberts, A., \& Baldacchino, G. (2017). Resilience and tourism in islands: Insights from the Caribbean. In R.W. Butler (Ed.), Tourism and resilience (pp. 150-162). CABI. https://doi.org/10.1079/9781780648330.0150

Allaby, E. (2020, April 22). Pregnant Italians on virus-free island told to deliver elsewhere. Al Jazeera News. $\quad$ https://www.aljazeera.com/news/2020/04/pregnant-italians-fear-delivervirus-patients-200422090956571.html

Amato, G. (2020, 28 May). Aerei, prezzi alle stelle per la fase 2. Federconsumatori: "Sicilia-Roma oltre $i \quad 500$ euro”. La https://palermo.repubblica.it/cronaca/2020/05/28/news/aerei prezzi alle stelle per la fase 2 federconsumatori sicilia-roma oltre i 500 euro $-257853360 /$

Associazione Nazionale Comuni Isole Minori. (2020, 22 May). Manifesto dei Sindaci e dei Cittadini delle Isole Minori. https://www.ancim.it/manifesto-dei-sindaci-e-dei-cittadinidelle-isole-minori.htm 
Karl Agius et al.

ANSA. (2020). Sicilia: sindaco, ok a stato calamità per Lampedusa e Linosa. ANSA.it. https://www.ansa.it/sicilia/notizie/2020/06/26/sicilia-sindaco-ok-a-stato-calamitape 5ae0e2b0-a17a-424b-9762-ce59dcfc162c.html

Baldacchino, G. (2021). Extra-territorial quarantine in pandemic times. Political Geography, 85, 102302. https://doi.org/10.1016/j.polgeo.2020.102302

Baldacchino G. (2020). Editor's Note: Small states and territories and Coronavirus. Small States \& Territories, 3(1), 4.

Baldacchino, G. (2017). Europe and island tourism. EuropeNow. https://www.europenowjournal.org/2017/09/05/europe-and-island-tourism/

Baldacchino, G. (2015). More than island tourism: Branding, marketing and logistics. In G. Baldacchino (Ed.), Archipelago tourism: Policies and practices (pp. 1-18). Ashgate. https://doi.org/10.4324/9781315567570-7

Baldacchino, G. (2008). Studying islands: on whose terms? Some epistemological and methodological challenges to the pursuit of island studies. Island Studies Journal, 3(1), 37-56.

Baldacchino, G. (2007). Fixed links and the engagement of islandness: Reviewing the impact of the Confederation Bridge. The Canadian Geographer/Le Geographe Canadien, 51(3), 323-336. https://doi.org/10.1111/j.1541-0064.2007.00181.x

BBC News. (2020, September 1). Lampedusa: Migrant with coronavirus gives birth in helicopter. BBC News: Europe migrant crisis. https://www.bbc.com/news/world-europe$\underline{53993465}$

BlogSicilia. (2020). La regione valuta l'apertura di un ospedale a Lampedusa. Politica. https://www.blogsicilia.it/agrigento/la-regione-valuta-lapertura-di-un-ospedale-alampedusa/538179/

Borg, A. (2020, March 20). Watch: 11 new coronavirus cases - 1st case reported in Gozo. Newsbook. https://newsbook.com.mt/en/live-press-conference-on-covid-19-cases/

Briguglio, L. (1995). Small island developing states and their economic vulnerabilities. World Development, 23(9), 1615-1632. https://doi.org/10.1016/0305-750x(95)00065-k

Canavan, B. (2013). The extent and role of domestic tourism in a small island: The case of the Isle of Man. Journal of Travel Research, 52(3), 340-352. https://doi.org/10.1177/0047287512467700

Clark, V. L. P., \& Creswell, J. W. (2008). The mixed methods reader. Sage.

Comune di Pantelleria. (2020a, March 4). Il Sindaco - Avviso Alla Cittadinanza. DPCM 4 Marzo 2020. $\quad \underline{\text { http://www.comunepantelleria.it/wp- }}$ content/uploads/2020/03/AVVISO-ALLA-CITTADINANZA.pdf

Comune di Pantelleria. (2020b, March 10). Il Sindaco - Avviso Alla Cittadinanza. http://www.comunepantelleria.it/wp-content/uploads/2020/03/AVVISOCORONAVIRUS-10032020.pdf

Comune di Pantelleria. (2020c, March 22). Ordinanza sindacale n. 26 del 22/03/2020. http://www.comunepantelleria.it/wpcontent/uploads/2020/03/doc03517020200322115516.pdf

Comune di Pantelleria. (2020d, May 8). I Sindaci Delle Isole Minori Scrivono Al Presidente Musumeci E Chiedono Un Incontro Urgente [Image attached]. Facebook. 
https://www.facebook.com/comunedipantelleria/photos/pb.452225525446.2207520000../10163242301730447/

Costa, M. (2020, March 31). Coronavirus: Non-essential travel between Malta and Gozo stopped.

Malta

Today.

https://www.maltatoday.com.mt/news/national/101401/watch coronavirus nonesse ntial travel between malta and gozo stopped\#.XsTh1GgzbIU

Cozzo, M. (2020, April 28). Ente Parco in conferenza per il turismo: Pantelleria Covid-free, perfetta per il post Coronavirus. Il Giomale di Pantelleria. https://www.ilgiornaledipantelleria.it/ente-parco-in-conferenza-per-il-turismopantelleria-covid-free-perfetta-per-il-post-coronavirus/

Craig, A.T., Heywood, A.E., \& Hall, J. (2020). Risk of COVID-19 importation to the Pacific islands through global air travel. Epidemiology and Infection, 148(71), 1-5. https://doi.org/10.1017/s0950268820000710

Dominioni, I. (2020). Isolamento: A Favignana la scuola digitale si fa da vent'anni. Linkiesta. https://www.linkiesta.it/2020/05/scuola-digitale-favignana/

Ente Parco Nazionale Isola di Pantelleria. (2020). Parco Nazionale Isola di Pantelleria. Parks.it. http://www.parks.it/parco.nazionale.isola.pantelleria/Eindex.php

European Commission. (2020a). Communication from the Commission to the European Parliament, the Council, the European Economic and Social Committee and the Committee of the Regions: Tourism and transport in 2020 and beyond. https://op.europa.eu/en/publication-detail//publication/ea94e5a7-9678-11ea-aac4-01aa75ed71a1/language-en

European Commission. (2020b, June 11). Coronavirus: Commission recommends partial and gradual lifting of travel restrictions to the EU after 30 June, based on common coordinated approach. https://ec.europa.eu/commission/presscorner/detail/en/ip 201035.

Finn, M., Walton, M., \& Elliott-White, M. (2000). Tourism and leisure research methods: Data collection, analysis, and interpretation. Longman.

Galetic, F. (2020). The influence of COVID19 on tourism - the case of the island of Hvar. Economic and Social Development: Book of Proceedings, 60-68.

Gallia, A. (2012). La valorizzazione dei beni culturali e ambientali per lo sviluppo delle isole minori italiane. Rivista giuridica del Mezzogiorno, 26(4), 929-962.

Gedi Visual (2020). Coronavirus, la situazione in Italia. Le Repubblica. https://lab.gedidigital.it/gedi-visual/2020/coronavirus-i-contagi-in-italia/

Gozo Business Chamber. (2020a). Post COVID-19: Policy and Strategic Document. https://gozobusinesschamber.org/post-covid-19-policy-and-strategic-document/

Gozo Business Chamber. (2020b). The Gozo Business Chamber publishes its Budgetary Proposals https://gozobusinesschamber.org/the-gozo-business-chamber-publishes-itsbudgetary-proposals/

Gozo Business Chamber. (2020c). Post COVID-19: Policy and Strategic Document. Retrieved from https://gozobusinesschamber.org/post-covid-19-policy-and-strategicdocument/

Grydehøj, A., \& Casagrande, M. (2020). Islands of connectivity: Archipelago relationality and transport infrastructure in Venice Lagoon. Area, 52(1), 56-64. https://doi.org/10.1111/area.12529 
Karl Agius et al.

Grydehøj, A., Kelman, I., \& Su, P. (2020). Island geographies of aeparation and Cohesion: The coronavirus (COVID-19) pandemic and the geopolitics of Kalaallit Nunaat (Greenland). Tijdschrift voor economische en sociale geografie, 111(3), 288-301. https://doi.org/10.1111/tesg.12423

House of Representatives. (2020). Report of the Standing Committee for Gozo Affairs on the impact of COVID-19 on Gozo and the way forward. https://parlament.mt/media/107637/pr201399a.pdf

Il Giornale di Pantelleria. (2020, October 31). Pantelleria e Pelagie aliscafi fino al 31 ottobre. Tutti gli orari nell'articolo. Il Giornale di Pantelleria. https://www.ilgiornaledipantelleria.it/pantelleria-e-pelagie-aliscafi-fino-al-31ottobre-tutti-gli-orari-nellarticolo/

La Sicilia. (2020, May 15). Fase 2: sindaco Lampedusa, 'pochi posti sui voli, isolani bloccati a Palermo'. La Sicilia. https://www.lasicilia.it/take/sicilia/341851/fase-2-sindacolampedusa-pochi-posti-sui-voli-isolani-bloccati-a-palermo.html

Libero Consorzio Comunale di Trapani. (2019). Tav.4- Favignana: Movimento Turistico Ricettivo Mensile Anno 2019 - Dati Provviso. http://www.consorziocomunale.trapani.it/provinciatp/images/FAVIGNANA agg20 19.pdf

LiveSicilia. (2020, May 26). Lampedusa, sit-in di protesta degli imprenditori turistici. https://livesicilia.it/2020/05/26/lampedusa-sit-in-di-protesta-degli-imprenditorituristici/?refresh ce

Lucchini, E. (2010, February 10). Ho un video prof: le lezioni sono via web. Corriere della Serra. https://www.corriere.it/scienze/10 febbraio 04/marettimo 46e0d49c-1198$11 \mathrm{df}-806 \mathrm{e} 00144 \mathrm{f02aabe}$. shtml?refresh ce-cp

Mangione, G. R., Mosa, E., \& Pettenati, M. C. (2015). Dalla Gelmini alla Giannini. Il Piano Nazionale Scuola Digitale, i PON disciplinari e il ruolo dell'INDIRE nella formazione continua degli insegnanti. Formazione \& Insegnamento. Rivista internazionale di Scienze dell'educazione e della formazione, 13(3), 139-166.

Mariano, K. (2020). Domestic tourism could save COVID-19-stricken destinations. Travel Daily. https://www.traveldailymedia.com/domestic-tourism-could-save-covid-19-strickendestinations/

McCall, G. (1997, May 8-10). Nissology: A debate and discourse from below [Paper presentation]. Cultural Heritage in Islands and Small States Conference, Valletta, Malta.

Mhalla, M. (2020). The impact of novel coronavirus (COVID-19) on the global oil and aviation markets. Journal of Asian Scientific Research, 10(2), 96-104. https://doi.org/10.18488/journal.2.2020.102.96.104

Micallef Darmenia, E. (2020, September 2). There are nine active cases of COVID-19 In Gozo, confirms Gozo Minister. Lovin Malta. https://lovinmalta.com/news/there-are-nineactive-cases-of-covid-19-in-gozo-confirms-gozo-minister/

Mobilita. (2020). La compagnia aerea DAT risponde ai sindaci di Lampedusa e Pantelleria. https://mobilita.org/2020/05/30/la-compagnia-aerea-dat-risponde-ai-sindaci-dilampedusa-e-pantelleria/ 
Muscat, J. (2014). Gozo tourism: figuring the figures. Gozo Observer, 31, 30-31. https://www.um.edu.mt/library/oar/bitstream/123456789/15241/1/Gozo\%20Touri sm\%20-\%20Figuring\%20the \%20figures.pdf

National Statistics Office. (2020). Regional Statistics Malta 2020. https://nso.gov.mt/en/publicatons/Publications by Unit/Documents/02 Regional Statistics (Gozo Office)/2020/Regional Statistics Malta-2020\%20Edition.pdf

National Statistics Office. (2019). Key figures for Malta: Visuals and words - 2019 Edition. https://nso.gov.mt/en/nso/Media/Salient-Points-ofPublications/Documents/Key\%20Figures\%20for\%20Malta\%20\%202019\%20Edition/Malta\%20In\%20Figures\%20-\%202019.pdf

Orr, I. (2020). Covid-19 and islands (States, territories and sub-national island jurisdictionsSNIJs) Landscape format, data as at 26 November. International Small Islands Studies Association. http://www.isisa.org/userfiles/Covid 19 26Nov2020 update Iain O.doc

Papatheodorou, A. (2001). Tourism, transport geography and industrial economics: A synthesis in the context of Mediterranean Islands. Anatolia, 12(1), 23-34. https://doi.org/10.1080/13032917.2001.9686996

Pelosi, G. (2020). L'Italia "chiama" i turisti Ue, dal 3 giugno riaprono gli aeroporti. Dal 15 Francia, Germania e Grecia. Il Sole 24 Ore. https://www.ilsole24ore.com/art/l-italia-riapreturisti-ue-3-giugno-15-francia-germania-e-grecia-ADrJJgR?refresh ce=1

Pes, A. (2020). Pantelleria, L'isola a "Contagio Zero" per Questa Estate 2020. Green Planet News. https://www.greenplanetnews.it/pantelleria-lisola-a-contagio-zero-per-questaestate-2020/

Putz, C. (2020, May 6). Where Are There Still No COVID-19 Cases? An Updated Analysis. The Diplomat. https://thediplomat.com/2020/05/where-are-there-still-no-covid-19cases-an-updated-analysis/

Rossi, M. (2020, May 24). I viaggi del cuore. Pantelleria, l'isola figlia del vento. IO Donna. https://www.iodonna.it/lifestyle/viaggi/2020/05/24/vacanza-pantelleriadistanziamento-sociale-naturale/

Ruta, G. (2020, June 10). Sicilia, la top ten delle vacanze in era Covid: San Vito Lo Capo e Favignana in vetta. Palermo la Repubblica. https://palermo.repubblica.it/cronaca/2020/06/10/news/sicilia la top ten delle vac anze in era covid san vito lo capo e favignana in vetta-258878869/

Ryall, J. (2020, May 19). Zero cases: How Pacific islands kept coronavirus at bay. DW. https://www.dw.com/en/zero-cases-how-pacific-islands-kept-coronavirus-at-bay/a$\underline{53495263}$

Savvides, N., Al-Youssef, J., Colin, M., \& Garrido, C. (2014). Journeys into inner/outer space: Reflections on the methodological challenges of negotiating insider/outsider status in international educational research. Research in Comparative and International Education, 9(4), 412-425. https://doi.org/10.2304/rcie.2014.9.4.412

Scifo, A. D. (2020, May 28). Linosa, medico di guardia rimandato via per timore del coronavirus. Palermo la Repubblica. https://palermo.repubblica.it/cronaca/2020/03/28/news/linosa medico di guardia rimandato via per timore del coronavirus-252546354/ 
Karl Agius et al.

Sfragasso, G. (2020). Il lock-down visto da Marettimo. Palermo la Repubblica. https://video.repubblica.it/edizione/palermo/coronavirus-il-lockdown-visto-damarettimo/358722/359278

Sindico, F., Sajeva, G., Sharman, N., Berlouis, P., \& Ellsmoor, J. (2020). Islands and COVID19: A Global Survey. Strathclyde Centre for Environmental Law and Governance \& Island

Innovation.

https://www.strath.ac.uk/media/1newwebsite/departmentsubject/law/strathclydecen treforenvironmentallawandgovernance/pdf/eilean/Islands and COVID Booklet v5 pages-1.pdf

Spilanis, I., Kizos, T., \& Petsioti, P. (2012). Accessibility of peripheral regions: Evidence from Aegean islands. Island Studies Journal, 7(2), 199-214.

Stoffelen, A. (2019). Disentangling the tourism sector's fragmentation: A hands-on coding/post-coding guide for interview and policy document analysis in tourism. Current Issues in Tourism, 22(18), 2197-2210. https://doi.org/10.1080/13683500.2018.1441268

Suryani, A. (2013). Comparing case study and ethnography as qualitative research approaches. Jurnal Ilmu Komunikasi, 5(1), 117-127. https://doi.org/10.24002/jik.v5i1.221

The Shift. (2020, April 13). Gozo Hospital staff worried about reliability of coronavirus tests. The Shift: News. https://theshiftnews.com/2020/04/13/gozo-hospital-staff-worriedabout-reliability-of-coronavirus-tests/

TP24. (2020, April 22). Coronavirus, l'aereo per Lampedusa e Pantelleria è pieno e i passeggeri lo fermano. Economia. https://www.tp24.it/2020/04/22/economia/coronavirus-1-aereoper-lampedusa-e-pantelleria-e-pieno-e-i-passeggeri-lo-fermano/148405

TP24. (2019, May 22). Il turismo in provincia di Trapani/2. Ecco $i$ Comuni che vanno bene, e quelli messi male. Economia. https://www.tp24.it/2019/05/22/economia/turismotrapani/134892

TVM. (2020, July 10). Reduction in fares on Gozo Channel vessels. TVM: Current Affairs. https://www.tvm.com.mt/en/news/reduction-in-fares-on-gozo-channel-vessels/

University of Strathclyde. (2020). Islands and Covid-19. Strathclyde Centre for Environmental Law and Governance. https://www.strath.ac.uk/research/strathclydecentreenvironmentallawgovernance/ou rwork/research/labsincubators/eilean/islandsandcovid-19/

Vella, M. (2020, April 8). First Malta COVID-19 death is Gozo woman, 92. Malta Today. https://www.maltatoday.com.mt/news/national/101575/first malta covid19 death is gozo woman 90\#.X8 $5 \mathrm{mWhKgcA}$

Wearing, S., Cynn, S., Ponting, J., \& McDonald, M. (2002). Converting environmental concern into ecotourism purchases: A qualitative evaluation of international backpackers in Australia. Journal of Ecotourism, 1(2-3), 133-148. https://doi.org/10.1080/14724040208668120

Weaver, D. B. (1998). Peripheries of the periphery: Tourism in Tobago and Barbuda. Annals of Tourism Research, 25(2), 292-313. https://doi.org/10.1016/s0160-7383(97)00094-7

Yang, Y., Zhang, H., \& Chen, X. (2020). Coronavirus pandemic and tourism: Dynamic stochastic general equilibrium modeling of infectious disease outbreak. Annals of Tourism Research, 83, 102913. https://doi.org/10.1016/j.annals.2020.102913 